\title{
United Nations Multidimensional Integrated Stabilization Mission in Mali
}

\section{Introduction}

Mali is a semi-presidential republic whose territory is located in the Sahel and South Sahara. Complex geographic conditions, an area of 1.2 million $\mathrm{km}^{2}$ and a large number of neighboring states with permeable borders create conditions for instability, which is exacerbated by the current government crisis. Its neighboring countries are Algeria in the north, Niger in the east, Burkina Faso and Côte d'Ivoire in the south and Guinea, Senegal and Mauritania in the west. The United Nations Multidimensional Integrated Stabilization Mission in Mali (MINUSMA), which is being implemented in Mali, has three Czech soldiers in its structure, and 11 members of the Czech Army have been included in the UN unit so far.

Analysis of the historical roots of the conflict in Mali, implementation of steps to support the political process and assistance in stabilizing Mali are dependent on the success of the implementation of the UN mandate in meeting the mission objectives. Due to the fact that the change in the security level affects the neighboring countries, especially the Central African Republic, the analysis includes a comparison of the development of the two countries.

The aim of the article is to analyze the MINUSMA mandate, military and non-military personnel participation in comparison to the achieved results. 


\section{Causes of the conflict in 2012}

The Mande ethnic groups include Bambara, Malinke, and Sarakole ethnicities and represent $50 \%$ of the total population. Other ethnic groups include the Peul (17\%), the Voltaic (12\%), the Songhai (6\%) and the Tuareg and Moor (10\%). ${ }^{1}$

Mali is characterized by ethnic tolerance, with the exception of the Tuareg ethnic group. The Tuareg inhabit the northern part of Mali and a part of the Sahara desert in Algeria, Niger and Libya. The number of members of the Tuareg ethnic group is estimated to be between 1 and 1.5 million. The political-economic problems of Niger and Mali developed in the 1960s-1990s and led to a high Tuareg migration to neighboring countries. The Tuareg differ significantly from other ethnic groups not only visually, but also in terms of language, culture, and way of life and above all a specific value system. Historically, they were desert nomads who have traditionally opposed central governments. Continuing dissatisfaction with government policy leads to long-term conflicts, mostly of a low intensity. ${ }^{2}$

The Arab Spring was a trigger that changed the security situation in the region and prompted the return of the Tuareg. The returnees were former members of the Libyan armed forces and engaged in the activities of the National Movement for the Liberation of Azawad (MNLA). The disputed territories of the Sahel and Sahara, that include the territory of Niger and Algeria, were soon occupied by MNLA. The operation started in January 2012. As a direct result of territorial expansion, the level of Tuareg-Arab unity was reduced.

In order to maintain unity, MNLA began to work with the Islamic group Ansar Dine, ${ }^{3}$ aiming to create a state in the north of Mali that would implement the sharia-based principles of orthodox Islam. The Islamic group Ansar Dine worked with the AQIM (Al-Qaeda in the Islamic Maghreb) terrorist groups ${ }^{4}$ and $\mathrm{MUJAO}^{5}$ (The Movement for Unity and Jihad in West Africa), which was supposed to have helped

${ }^{1}$ H. Solomon, "Ansar Dine in Mali: Between Tuareg nationalism and Islamism," [in:] H. Solomon, Terrorism and Counter-Terrorism in Africa, London 2015, pp. 67-84.

2 M. Kohlert, “Občanská válka v Mali. Existuje naděje na úplný mír?” Africký informačni portál 5.03.2017, http://africkyportal.cz/clanky/komentar-obcanska-valka-v-mali-existuje-nadejena-uplny-mir (accessed: 6.04.2019).

${ }^{3}$ Militant group of Salafi Tuareg, who played a crucial role in the takeover of jihad in northern Mali. Iyad Ag Ghali, former leader of the Tuareg rebellion of the 1990s, formed the group after he had not managed to become the leader of MNLA. The Al Qaeda in the Islamic Maghreb group supplied Ansar with weapons and warriors.

${ }^{4}$ It was created in January 2007 from the Algerian Salafist Preaching and Fighting Group (GSPC) and its predecessor, the Armed Islamic Group (GIA), which fought against the secular Algerian government after promising Al-Qaeda (AQ) devotion. The aim is to create an Islamic state across North Africa. It is responsible for trafficking and kidnapping for ransom.

5 A jihadist militant group, which broke up with AQIM in October 2011, allegedly due to disagreement with the kidnapping distribution of revenue and dominance of Algerian nationals in the leadership. Unlike AQIM, most MUJAO members are Malian (Tilemsi Arabs, Fulani and Songhai) operating in the Gao area. In August 2013, MUJAO teamed up with Mokhtar Belmokhtar 
it to create an independent state. The Islamic group Ansar Dine gained significant influence in the northern region, and sharia law began to be implemented in the life of society. Like other Islamist groups, it has captured the world's attention by destroying historic sites - the tombs of the Sufi saints in Timbuktu, a UNESCO World Heritage Site. ${ }^{6}$

The sovereign state of Azawad was declared by MNLA in March 2012, and the administration of the newly formed state was co-sponsored by the Islamic group Ansar Dine. But between these two groups, not only did ideological differences soon appear. The different goals of MNLA seeking to establish a separate Tuarean state and Ansar Dine seeking to establish Islamic law throughout Mali have led to contradictions. MNLA disagreed with the influence of AQIM on governance, which was the largest partner of Ansar Dine. The disagreements culminated in an armed conflict between the two groups in June 2012. The factual winner of the dispute was the Ansar Dine group, which eliminated the influence of MNLA on the management of the "state" while MNLA members were pushed out of all larger cities.

Another change in the security situation was caused by the March 2012 conflict when the Malian army carried out a military coup, which resulted in the overthrow of the Mali and Amadou Toumani Touré governments. The main reason for the overthrow was the underfunding of the army and insufficient armament. Thus, the army was unable to face the well-armed Tuareg and could not respond adequately to eliminate unauthorized requests. Paradoxically, the army has provided the insurgents with space to consolidate positions and advance. The coup d'état was negatively received by the international community. Not only was the country's democratic development interrupted, but the military junta, led by Amada Haya Sanaga, took over the leadership of the country. The partial improvement of the country's stability was the result of the work of the ECOWAS (Economic Community of West African States). Dioncounda Traoré was appointed to head the interim government.

Radical Islamists soon began to expand their influence and began to occupy territories closer to the capital of Mali - Bamako. The low level of morality and the high degree of desertion of the Malian army were the main causes of the fact that state armed forces were unable to effectively face the rapid advance of Islamic groups. On September 24, 2012, the Interim President Traoré, supported by the army, officially asked the UN for military assistance to help stop the Islamist advance and bring the northern territory under the control of the Malian government.

al Muwaqi'un bil-Dima to create "Al Murabitun" and took responsibility for the attacks on Arlita's French uranium mine and the army barracks in Agadez, Niger.

6 Česká televize, http://www.ceskatelevize.cz/ct24/svet/1159247-islamiste-znicili-v-mali-dalsi-dve-sufijske-hrobky (accessed: 9.04.2018). 


\section{Promoting the political process and Mali stabilization assistance}

On April 25, 2013, the UN Security Council unanimously approved the creation of UN peacekeeping forces of 12,600 in West African Mali. In accordance with Chapter VII of the United Nations Charter, the Security Council has decided to set up a UN Multidimensional Integrated Stabilization Mission in Mali (MINUSMA) from July 1, 2013. The UN mission had an immediate impact on the African Mission for International Support for Mali (AFISMA). AFISMA was a project of the ECOWAS. The UN Secretary-General subsequently incorporated the United Nations Office in Mali (UNOM) into the structure of the operating units and appointed Special Representatives for Mali and the Head of Mission, who was the official authority to coordinate UN activities.

According to the UN Resolution 2100 (2013), MINUSMA was to comprise 11,200 military personnel, including Rapid Reaction Reserve Battalions and 1,440 police officers. The Security Council called on the Member States to provide troops and police with adequate capacities and equipment. ${ }^{7}$

The European Union (EU) has also responded to the situation in Mali and has begun preparing and subsequently implementing the European Union Training Mission in Mali (EUTM Mali). EUTM Mali is a non-combat mission dedicated to training and advising the Mali armed forces. It is an EU multinational military training mission of 569 members of 17 European and 5 non-European countries. The area of action is Bamako. Participating countries are members of the armed forces of 17 countries of the EU (Austria, Belgium, Czech Republic, Denmark, Estonia, Finland, France, Germany, Italy, Latvia, Lithuania, Netherlands, Norway, Portugal, Sweden, Switzerland, United Kingdom) and 5 non-member countries (Albania, Montenegro, Georgia, Moldova, Serbia). The EU mission coordinates activities with UN MINUSMA. The headquarters of the mission is located in the capital of Bamako and the training camp is in Koulikoro, located $60 \mathrm{~km}$ northeast of Bamako. The training camp is a location for mobile advisory and training teams (CMATT).

7 United Nations, "Security Council establishes peacekeeping force for Mali effective 1 July, unanimously adopting Resolution 2100 (2013)," https://www.un.org/press/en/2013/sc10987.doc.htm (accessed: 9.04.2018). 


\section{MINUSMA mandate}

Due to the high level of instability, the mandate of MINUSMA was extensive and the responsibilities of Resolution 2100 could be divided as presented in Table 1 .

Table 1. Mission mandate areas

\begin{tabular}{|c|c|}
\hline Area & Content \\
\hline $\begin{array}{l}\text { Stabilization of key population } \\
\text { centers and support for the } \\
\text { re-establishment of state } \\
\text { authority in the country }\end{array}$ & $\begin{array}{l}\text { - support for interim authorities in Mali } \\
\text { - stabilization of key centres, especially in the north } \\
\text { - eliminating threats and taking active measures to prevent the } \\
\text { return of armed forces to stabilized areas } \\
\text { - restoration of the Mali security sector } \\
\text { — establishing government, law and justice } \\
\text { - mine clearance } \\
\text { - Disarmament, Demobilization and Reintegration process } \\
\text { (DDR) }\end{array}$ \\
\hline $\begin{array}{l}\text { Promoting political dialogue } \\
\text { and electoral processes }\end{array}$ & $\begin{array}{l}\text { - restoration of constitutional order } \\
\text { - establishing democratic governance, national unity, applying } \\
\text { good services and building trust at national and local level } \\
\text { - support and assistance in organizing inclusive, free, } \\
\text { transparent and fair elections }\end{array}$ \\
\hline $\begin{array}{l}\text { Protection of civilians and UN } \\
\text { personnel }\end{array}$ & $\begin{array}{l}\text { - protection of civilians under the immediate threat of } \\
\text { physical violence } \\
\text { - providing special protection for women and children }\end{array}$ \\
\hline $\begin{array}{l}\text { Promoting and protecting } \\
\text { human rights }\end{array}$ & $\begin{array}{l}\text { - monitoring the level of respect for human rights } \\
\text { — taking action to establish a higher level of respect for human } \\
\text { rights through the UN Security Council }\end{array}$ \\
\hline Promoting humanitarian aid & — creation of safe distribution areas \\
\hline Preserving cultural heritage & $\begin{array}{l}\text { - cooperation with UNESCO in the protection of cultural } \\
\text { monuments }\end{array}$ \\
\hline $\begin{array}{l}\text { Promotion of national and } \\
\text { international law }\end{array}$ & $\begin{array}{l}\text { - punishisng war crimes } \\
\text { — punishing crimes against humanity }\end{array}$ \\
\hline
\end{tabular}

Source: K. Vargová, Role mírových misi OSN při řešeni konfliktů: komparace mírových misí v Mali a Demokratické republice Kongo, dissertation at University of West Bohemia, Plzeň 2016, p. 45.

\section{MINUSMA mission activities}

The contingent units, mission experts, and officers in March 2017 were comprised of 13,289 military personnel from 50 countries. The participating countries were Armenia, Austria, Bangladesh, Belgium, Benin, Bosnia and Herzegovina, 
Burkina Faso, Cambodia, Cameroon, Chad, China, Czech Republic, Denmark, Egypt, Estonia, Ethiopia, Finland, France, Gambia, Germany, Ghana, Guinea, Guinea Bissau, Indonesia, Italy, Ivory Coast, Jordan, Kenya, Lithuania, Liberia, Latvia, Mauritania, Nepal, Netherlands, Niger, Nigeria, Norway, Portugal, Romania, Salvador, Senegal, Sierra Leone, Sri Lanka, Sweden, Switzerland, Togo, United Kingdom, USA, Yemen.

The mandate assumes that UN Mine Action Center (UNMAC) military personnel will work with local communities and local military personnel to achieve greater mutual understanding and create the conditions to establish lasting peace. The main objective of the UN mandate is to protect civilians. In performing the mission's mandate, military personnel may be extended to include activities related to:

- monitoring disputed borders,

— implementing peace processes in post-conflict areas,

- performing security within a conflict zone,

— protecting civilians,

— using military personnel from a country with training and support.

\section{Mandate of MINUSMA peacekeeping police personnel}

The United Nations Police (UNPOL) is an important part of the UN force. UNPOL is especially significant in the communities where it renews and increases the level of security. UNPOL members focus on advising national police forces and implementing international human rights standards. Their presence strengthens public order, law enforcement, and the rule of law. The contributing states are Bangladesh, Benin, Burkina Faso, Burundi, Chad, Cameroon, Denmark, Egypt, Finland, France, Germany, Guinea, Hungary, Ivory Coast, Jordan, Niger, Netherlands, Romania, Sweden, Switzerland, Togo, Tunisia, and Yemen. ${ }^{8}$ UNPOL consists of police officers from different member states: Individual Police Officers (IPO) and Police Units (FPU). MINUSMA had 1,742 police officers, including 10 experts, 309 IPOs and 1,433 FPUs. MINUSMA's police force carries out the mission's mandate together with military and civilian forces.

UNPOL was commissioned to:

— provide expertise and assistance,

— conduct territorial and group operational assessments,

8 United Nations, "MINUSMA: Activities," https://minusma.unmissions.org/en/military (accessed: 9.04.2018). 
- train and strengthen the national police,

- develop and adapt technical guidelines to local conditions,

- assist the national police in strategic planning and technical support,

— contribute to post-conflict security sector reform.

The stability of the region is based on the ability of the nation states to keep the population in a defined area and provide them with material and other assistance. Also, the international community is responsible for creating an adequate number of peacekeeping operations that can act according to the security situation. To illustrate this, the authors compared the numbers of UN peacekeepers close to the low level of the Human Development Index (HDI) (Mali 0.419 - 179th position, Central African Republic 0.350 - 187th position) and the fact that they are among the African Union countries. An important geographic factor is also the fact that the area covers $1,240,000 \mathrm{~km}^{2}$ and the Central African Republic has an area of $622,984 \mathrm{~km}^{2}$.

\section{Comparison of peacekeeping operations MINUSMA and MINUSCA}

Table 2. Comparison of MINUSMA and MINUSCA personnel

\begin{tabular}{|l|c|c|}
\hline & Mali (MINUSMA) & $\begin{array}{c}\text { Central African Republic } \\
\text { (MINUSCA) }\end{array}$ \\
\hline \multicolumn{3}{|c|}{ Total staff numbers } \\
\hline Civilians & 1,351 & 13,461 \\
\hline Contingent units & 11,351 & 77,456 \\
\hline MISI experts & 31 & 1,349 \\
\hline Police & 1,741 & 10,831 \\
\hline Staff officers & 409 & 1,908 \\
\hline UN volunteers & 161 & 1,587 \\
\hline \multicolumn{3}{|c|}{ Uniformed personnel } \\
\hline Military personnel & 13,289 & 11,650 \\
\hline Police (including formed units) & 1,920 & 2,080 \\
\hline
\end{tabular}

Source: Author's own work based on United Nations, "United Nations Multidimensional Integrated Stabilization Mission in Mali," https://peacekeeping.un.org/en/mission/minusma (accessed: 9.04.2018); United Nations, "Facts and Figures," https://minusca.unmissions.org/en/facts-and-figures (accessed: 9.04.2018).

Also, the mission costs and mission duration, as shown in the Table 3, are important indicators. 
Table 3. Characteristics of UN missions

\begin{tabular}{|l|c|c|}
\hline Reason & Mali & Central African Republic \\
\hline Start of the conflict & $\begin{array}{c}\text { ethnic differences, } \\
\text { territorial struggle }\end{array}$ & $\begin{array}{c}\text { ethnic and religious } \\
\text { differences }\end{array}$ \\
\hline Expenditure (1.07.2017-30.06.2018) & 2012 & 2013 \\
\hline Number of personnel & $1,048,000,000 \$$ & $882,800,000 \$$ \\
\hline Number of deaths & 15,044 & 106,592 \\
\hline
\end{tabular}

Source: Author's own work based on S. Sabrow, "Local perceptions of the legitimacy of peace operations by the UN, regional organizations and individual states - a case study of the Mali conflict," International Peacekeeping 24, 2017, no. 1, pp. 159-186; B. Lecocq et al., "One hippopotamus and eight blind analysts: A multivocal analysis of the 2012 political crisis in the divided Republic of Mali," Review of African Political Economy 40, 2013, pp. 343-357; United Nations, "United Nations Multidimensional Integrated Stabilization Mission in Mali," https://peacekeeping.un.org/en/mission/minusma (accessed: 9.04.2018); United Nations, "Facts and Figures," https://minusca.unmissions.org/en/facts-and-figures (accessed: 9.04.2018).

The development of the number of members of participating countries is an indicator of the interest of the states in stabilizing the region, which may influence the neighboring countries in the form of a domino effect with a long-lasting low level of security.

Table 4. Top 10 countries participating in MINUSMA

\begin{tabular}{|l|c|c|}
\hline \multicolumn{1}{|c|}{ State } & Members of the peace mission & Police mission officers \\
\hline Ethiopia & 8,173 & - \\
\hline Bangladesh & 6,153 & 779 \\
\hline India & 6,035 & - \\
\hline Pakistan & 6,004 & 1,070 \\
\hline Rwanda & 5,653 & 681 \\
\hline Nepal & 4,723 & - \\
\hline Tanzania & 2,541 & - \\
\hline Indonesia & 2,478 & - \\
\hline China & 2,437 & 775 \\
\hline Egypt & 2,349 & - \\
\hline
\end{tabular}

Source: Author's own work based on United Nations, "Troop and police contributors," https://peacekeeping.un.org/en/troop-and-police-contributors (accessed: 12.04.2019).

The UN requires the principle of impartiality to be applied, which ensures that the mandate is fulfilled impartially and the participating states do not favor one of the opponents. Adhering to the principle of impartiality is due to the diversification of participating national contingents. 
Table 5. Top 10 countries involved in MINUSCA

\begin{tabular}{|l|c|c|}
\hline \multicolumn{1}{|c|}{ State } & Members of the peace mission & Police mission officers \\
\hline Pakistan & 3,449 & - \\
\hline India & 2,624 & 280 \\
\hline Bangladesh & 1,698 & 178 \\
\hline South Africa & 1,165 & - \\
\hline Tanzania & 1,132 & - \\
\hline Uruguay & 922 & - \\
\hline Nepal & 890 & - \\
\hline Malawi & 850 & - \\
\hline Morocco & 862 & - \\
\hline Ghana & 478 & - \\
\hline
\end{tabular}

Source: United Nations, “Troop and police contributors,” https://peacekeeping.un.org/en/troop-and-police-contributors (accessed: 12.04.2019).

\section{Involvement of Czech Army members}

The Czech Republic joined the MINUSMA peacekeeping operation in Mali on September 1, 2016. The Czech Armed Forces sent a unit consisting of 25 soldiers from special forces to MINUSMA under Government Resolution No. 290 of April 22,2015 . The unit task was to support the efforts of MINUSMA Commander in the UN resolution reinforcement. Forces and resources came from the 601st Special Forces Group and operated in Mali under a mandate until December 31, $2016 .{ }^{9}$

The government of the Czech Republic discussed the possibility of sending a contingent in 2013, when the Minister of Foreign Affairs and the Minister of Defense were authorized to submit proposals for the Czech Republic's involvement in the resolution of the situation in Mali. On February 6, 2013, the government approved the operation of members of the Czech Army in the EUTM in Mali. In accordance with the laws of the Czech Republic, the posting was approved by both chambers of the Parliament of the Czech Republic. The mandate for the Czech Republic to operate in the EUTM, which was originally approved until June 30, 2014 , was subsequently extended to the end of 2014. The government approved the proposal for its extension on April 28, 2014.

On May 29, the extension of the mission was supported by the Senate and on June 18 by the Chamber of Deputies. On October 20, 2014, the government approved the "Proposal for the Force and Means of the Ministry of Defense Department in Foreign Operations in 2015 and 2016 with an Outlook for 2017" and

9 Ministerstvo obrany ČR, “Mise Army: Zahraniční mise Mali-MINUSMA,” http://www. mise.army.cz/aktualni-mise/minusma/mali-_-minusma-118539/(accessed: 9.04.2018). 
recommended the document to the Chamber of Deputies and the Senate of the Parliament of the Czech Republic. On April 18, 2016, the government agreed to deploy the Czech Army in foreign missions in 2017 and 2018 with an outlook for 2019. This document was approved by the Chamber of Deputies of the Parliament of the Czech Republic at the end of June 2016 and was passed by senators in July. By approving the document, it was possible to extend the deployment of forces and resources of the Ministry of Defense in the EUTM.

Table 6. Overview of the European Union Task Force Mali — EUTM

\begin{tabular}{|c|c|c|}
\hline $\begin{array}{l}\text { Task } \\
\text { group }\end{array}$ & Start date & Czech Army unit \\
\hline 1. TG & 14.03 .2013 & 43rd Airborne Battalion \\
\hline 2. $\mathrm{TG}$ & September 2013 & $\begin{array}{l}\text { 41st Mechanized Battalion } \\
\text { 7th Mechanized Brigade } \\
\text { 43rd Airborne Battalion }\end{array}$ \\
\hline 3. TG & 3.03 .2014 & 7th Mechanized Brigade \\
\hline 4. TG & 1.09 .2014 & 74th Motorized Battalion \\
\hline 5. TG & March 2015 & $\begin{array}{l}\text { 102nd Reconnaissance Battalion } \\
\text { 532nd Electronic Warfare Battalion }\end{array}$ \\
\hline 6. TG & September 2015 & 41st Mechanized Battalion \\
\hline 7. $\mathrm{TG}$ & 11.03 .2016 & 44th Light Motorized Battalion \\
\hline 8. TG & 9.09 .2016 & $\begin{array}{l}\text { 72nd Mechanized Battalion } \\
\text { Training Command - Military Academy }\end{array}$ \\
\hline 9. $\mathrm{TG}$ & 13.03 .2017 & $\begin{array}{l}\text { 71st Mechanized Battalion } \\
\text { Training Command - Military Academy } \\
\text { 44th Light Motorized Battalion } \\
\text { 102nd Reconnaissance Battalion }\end{array}$ \\
\hline 10. TG & 5.09 .2017 & $\begin{array}{l}\text { 131st Artillery Section } \\
\text { 41st Mechanized Battalion } \\
\text { 42nd Mechanized Battalion } \\
\text { 43rd Airborne Battalion } \\
\text { Training Command - Military Academy } \\
\text { 102nd Reconnaissance Battalion } \\
\text { Center of Operationally Tactical Command and Control Systems ACIS }\end{array}$ \\
\hline 11. TG & 9.03 .2018 & $\begin{array}{l}\text { 132nd Artillery Section } \\
\text { Military Health Agencies } \\
\text { 102nd Reconnaissance Battalion } \\
\text { Training Command — Military Academy } \\
\text { 74th Light Motorized Battalion }\end{array}$ \\
\hline
\end{tabular}

Source: Ministerstvo obrany ČR, "Mise Army: 1. jednotka AC̆R, Mali - EUTM,” http://www.mise. army.cz/scripts/detail.php?id=89087 (accessed: 9.04.2018); Ministerstvo obrany ČR, "Mise Army: 2. jednotka AČR, Mali — EUTM," http:/www.mise.army.cz/scripts/detail.php?id=95590 (accessed: 9.04.2018); Ministerstvo obrany ČR, “Mise Army: 7. jednotka AČR, Mali — EUTM,” http://www.mise.army.cz/scripts/detail. php?id=126371 (accessed: 9.04.2018); Ministerstvo obrany ČR, "Mise Army: Jednotky AČR, Mali — EUTM," http://www.mise.army.cz/scripts/detail.php?id=141777 (accessed: 9.04.2018). 
The Czech Army joined the EUTM to support the local government and take part in the training of the government's dedicated units. At the same time, it performed tasks related to the disarmament of the rebels.

The Czech Republic deployed task forces under the EUTM with the tasks outlined in Table 6. Task groups were equipped with IVECO, LRD 130 Cayman and $\mathrm{T}-815$ vehicles.

The UN Security Council has not been satisfied for a long time with the continuing delays in achieving the key provisions of the Peace and Reconciliation Agreement in Mali (herinafter referred to as "the Agreement"). Clear changes were required for the local population and government structures. The importance of deepening the cooperation of all participating parties arose not only from the 2018 election year in Mali, but also from the primary responsibility for implementing the steps of the peace process.

The UN Security Council calls for immediate and concrete action to fully and promptly implement the key provisions of the Agreement, in particular through:

1. Progress in the process of decentralization, through consultations between the parties to review and strengthen consensus on existing legislation and adopt legislation on the establishment of a territorial police unit.

2. The operation of temporary administrations in the north of Mali, including the allocation of the necessary human, technical and financial resources to carry out their tasks and to establish appropriate eligibility criteria.

3. Compliance with all obligations arising from applicable international law in the field of human rights protection.

4. Continuing efforts to fight impunity with the support of the UN MINUSMA.

5. Developing cooperation with all relevant actors in drafting legislation aimed at promoting national reconciliation.

The members of the Security Council reaffirmed their strong commitment to the sovereignty, independence and territorial integrity of Mali. They stressed that lasting peace and security in the Sahel region would not be achieved without a full, effective and inclusive implementation of the Agreement. ${ }^{10}$

However, despite the implementation of the peace agreement, the human rights situation in Mali remains worrying. Therefore, the published report stated that more than 600 human rights violations and abuses were committed from January 2016 to June 2017. More than 800 other incidents involving unidentified armed forces and threats to civilian lives have also occurred during the same period. In total, the violence affected more than 2,700 victims, including 441 people who were killed. ${ }^{11}$

10 United Nations, "Security Council press statement on Mali," https://minusma.unmissions. org/en/security-council-press-statement-mali-6 (accessed: 9.04.2018).

${ }^{11}$ United Nations, "Despite the implementation of the peace agreement, the human rights situation in Mali remains of concern," https://minusma.unmissions.org/en/despite-implementationpeace-agreement-human-rights-situation-mali-remains-concern (accessed: 9.04.2018). 


\section{Conclusion}

UN MINUSMA and the EUTM Mali cannot fully implement the process of restoring stability and eliminating the threats of terrorism in Mali and the surrounding fragile regions of the Sahel. The growing number of asymmetric attacks on mission officers is evidence of the fact that the increase in static UN units is not a solution to the region's instability, and the current peacekeeping mandate is not in line with the security situation. The implementation of post-conflict tasks requires the establishment of a peacekeeping mission to promote peace, which should be mobile and equipped with the means, technology and mandate of the UN to promote peace. Given the region's planted unit, it should have the capacity to fight terrorism, for which UN peacekeepers are not fully prepared.

Promoting peace through the current UN mission in Mali needs an adequate mandate from the UN Security Council. There is a clear discrepancy between the requirements of the UN Doctrine for Peace Operations and the current UN peacekeeping practices. The UN, and consequently the EU, should define and develop the notion of stabilization, and also respond to changes in UN doctrine. Doctrines should reflect citizens' needs and balance the relationship between the state and the citizens to bring lasting stability through a negotiated and inclusive peaceful solution.

A necessary condition for achieving an adequate level of security requires the separation of the fighting parties and the conditions for good governance set up. To succeed, a new concept of mission realization is needed. Experience also points to the need for a judicial solution for those who have broken the law. Experience also shows that rebel groups are temporarily willing to support the current government. The purpose of temporary support is to make UN troops depart.

The three activities required to achieve stability are:

1. participation of all political actors,

2. general election preparation,

3. defining the UN troops departure date and mission termination conditions.

The projection of the number of stabilization forces in a long-term operation requires a "gradual solution" that assumes the use of limited force followed by a small political mission. Achieving a defined level of stability would allow for a larger peace mission. This approach requires close cooperation between all UN and EU stakeholders. A gradual solution is that first, the more mobile military contingents are planted, and a larger peacekeeping mission will be established after stabilization. The generalization of the implementation of UN missions should lead to the abandonment of "super-camp" practices that lead to a "bunkerized" response to threats. The UN peacekeeping doctrine should be innovatively complemented by addressing extremism and criminal agenda issues. ${ }^{12}$ Non-repressive

12 J. Cockayne, "Chasing shadows: Strategic responses to organised crime in conflict-affected situations,” The RUSI Journal 158, 2013, no. 2, pp. 10-24. 
approaches in countering violent extremism (CVE) and transnational organized crime (TOC) should be gradually implemented. This approach should be more effective in implementing the stabilization strategy and contribute to achieving the defined objective.

The main obstacle to the success of the UN peacekeeping operation in Mali is the activities of terrorist groups and the level of organized crime in the Sahel region. Information sharing between the MINUSMA peacekeeping mission and the EUTM Mali, United Nations Office for West Africa and United Nations Office on Drugs and Crime missions is carried out discontinuously. A crucial step in achieving the long-term goals is the development of regional and cross-border planning and convergence of international Sahel strategies (ISS 2015). The UN should analyze and develop ways of further systematic information sharing and UN cooperation with Libyan expert groups, francophone entities outside the UN, US and EU structures, including the European Union Capacity Building Mission Sahel and, whenever possible, with national forces of the Human Rights Documentation and Dissemination Project.

The disputed territory of the Azawad should be given its own autonomy, that is, it would create its own parliament, which would manage territories at a certain level of government and its representatives would also be in Mali's parliament.

Ensuring economic growth and economic stability in Mali is another necessary step. Mali is on the list of countries of the world according to GDP per capita in 163rd place, so it is one of the poorest countries in the world. It can be argued whether the low standard of living contributes to the radicalization of the people of Mali, but based on the EU's efforts to stabilize the countries of origin of refugees, this is probably the most appropriate solution. The territory of Mali is predominantly desert, yet there are minerals needed for development, gold, oil and natural gas (which has not yet been withdrawn), rare earths (for the electrical industry and mining have not yet started). An important export article is cotton, which is grown as a textile fabric and as an oilseed. The agriculture of Mali can grow in crop production (millet, rice, maize and other cereals, vegetables, fruits) and livestock production (freshwater fish).

\section{Bibliography}

Bučka P., Gonos M., "Bezpečnost' priemyselných sietí v prostredí moderných kybernetických hrozieb," Acta Scientifica Academiae Ostroviensis. Sectio A, Nauki Humanistyczne, Społeczne i Techniczne 1, 2013, pp. 101-127.

Cabicarová M., Bajtová K., Korecki Z., "Food security in the refugee camp Dadaab," [in:] ICABR 2015: 10. International Conference on Applied Business Research, Brno 2015, pp. 167-177.

Česká televize, http://www.ceskatelevize.cz/ct24/svet/1159247-islamiste-znicili-v-mali-dalsi-dvesufijske-hrobky (accessed: 9.04.2018).

Cockayne J., "Chasing shadows: Strategic responses to organised crime in conflict-affected situations," The RUSI Journal 158, 2013, no. 2, pp. 10-24. 
Ivančík R., Jurčák V., Peace Operations of International Crisis Management, Ostrowiec Świętokrzyski 2013.

Keita K.,"Conflict and conflict resolution in the Sahel: The Tuareg insurgency in Mali," Small Wars \& Insurgencies 9, 1998, no. 3, pp. 102-128.

Kohlert M., "Občanská válka v Mali. Existuje naděje na úplný mír?” Africký informační portál 5.03.2017, http://africkyportal.cz/clanky/komentar-obcanska-valka-v-mali-existuje-nadeje-nauplny-mir (accessed: 6.04.2019).

Korecki Z., Cabicarová M., Rožňák P., Darkwah S.A., Distribuce humanitární pomoci a udržitelnost subjektů v humanitární operaci, Ostrava 2015.

Korecki Z., Staňková M., Cabicarová M., "Changing the level of food security due to changes in the level of safety in Central Africa," [in:] ICABR 2015: 10. International Conference on Applied Business Research, Brno 2015, pp. 507-521.

Lecocq B., Disputed Desert: Decolonisation, Competing Nationalisms and Tuareg Rebellions in Northern Mali, Leiden 2010.

Lecocq B., et al., "One hippopotamus and eight blind analysts: A multivocal analysis of the 2012 political crisis in the divided Republic of Mali," Review of African Political Economy 40, 2013, pp. 343-357.

Lecocq B., Klute G., "Tuareg separatism in Mali,” International Journal 68, 2013, no. 3, pp. 424 434.

Lecocq J.S., That Desert is Our Country: Tuareg Rebellions and Competing Nationalisms in Contemporary Mali (1946-1996), dissertation at Universiteit van Amsterdam, Amsterdam 2002.

Ministerstvo obrany ČR, "Mise Army: 1. jednotka AČR, Mali — EU TM," http://www.mise.army. cz/scripts/detail.php?id=89087 (accessed: 9.04.2018).

Ministerstvo obrany ČR, “Mise Army: 2. jednotka AČR, Mali — EUTM," http://www.mise.army. cz/scripts/detail.php?id=95590 (accessed: 9.04.2018).

Ministerstvo obrany ČR, "Mise Army: 3. jednotka AČR, Mali — EUTM," http://www.mise.army. cz/scripts/detail.php?id=102181 (accessed: 9.04.2018).

Ministerstvo obrany ČR, "Mise Army: 4. jednotka AČR, Mali — EUTM," http://www.mise.army. cz/scripts/detail.php?id=107909 (accessed: 9.04.2018).

Ministerstvo obrany ČR, "Mise Army: 5. jednotka AČR, Mali — EUTM," http://www.mise.army. cz/scripts/detail.php?id=114666 (accessed: 9.04.2018).

Ministerstvo obrany ČR, "Mise Army: 6. jednotka AC̆R, Mali — EU TM," http://www.mise.army. cz/scripts/detail.php?id=120414 (accessed: 9.04.2018).

Ministerstvo obrany ČR, "Mise Army: 7. jednotka AČR, Mali — EUTM," http://www.mise.army. cz/scripts/detail.php?id=126371 (accessed: 9.04.2018).

Ministerstvo obrany ČR, "Mise Army: 8. jednotka AČR, Mali — EU TM," http://www.mise.army. cz/scripts/detail.php?id=131328 (accessed: 9.04.2018).

Ministerstvo obrany ČR, "Mise Army: 9. jednotka AČR, Mali — EU TM", http://www.mise.army. cz/scripts/detail.php?id=136328 (accessed: 9.04.2018).

Ministerstvo obrany ČR, "Mise Army: 10. jednotka AČR, Mali — EU TM”, http://www.mise.army. cz/scripts/detail.php?id=141777 (accessed: 9.04.2018).

Ministerstvo obrany ČR, "Mise Army: 11. jednotka AČR, Mali — EU TM", http://www.mise.army. cz/scripts/detail.php?id=203765 (accessed: 9.04.2018).

Ministerstvo obrany ČR, "Mise Army: Zahraniční mise Mali — MINUSMA," http://www.mise. army.cz/aktualni-mise/minusma/mali-_-minusma-118539/ (accessed: 9.04.2018).

Randall S., "The demographic consequences of conflict, exile and repatriation: A case study of Malian Tuareg," European Journal of Population/Revue Européenne de Démographie 21, 2005, no. 2-3, pp. 291-320.

Rožňák P., Kubečka K., Země Visegrádu a migrace Fenomén procesu migrace a integrace a reintegrace v kontextu bezpečnosti zemí, Ostrava 2018.

Studia nad Autorytaryzmem i Totalitaryzmem 41, nr 3, 2019

(C) for this edition by CNS 
Sabrow S., "Local perceptions of the legitimacy of peace operations by the UN, regional organizations and individual states - a case study of the Mali conflict," International Peacekeeping 24, 2017, no. 1, pp. 159-186.

Solomon H., "Ansar Dine in Mali: Between Tuareg nationalism and Islamism," [in:] H. Solomon, Terrorism and Counter-Terrorism in Africa, London 2015, pp. 67-84.

United Nations, "Despite the implementation of the peace agreement, the human rights situation in Mali remains of concern," https://minusma.unmissions.org/en/despite-implementation-peace-agreement-human-rights-situation-mali-remains-concern (accessed: 9.04.2018).

United Nations, "MINUSMA: Activities," https://minusma.unmissions.org/en/military (accessed: 9.04.2018).

United Nations, "Preliminary agreement calling for the holding of a presidential election and inclusive peace talks in Mali," https://minusma.unmissions.org/sites/default/files/130618mali2_0. pdf (accessed: 9.04.2019).

United Nations, "Report on the situation of human rights in Mali from November 1, 2013 to May 31, 2014,” https://minusma.unmissions.org/sites/default/files/rapport_mali1nov2013_31mai2014. pdf (accessed: 9.04.2019).

United Nations, "Security Council establishes peacekeeping force for Mali effective 1 July, unanimously adopting Resolution 2100 (2013)," https://www.un.org/press/en/2013/sc10987.doc.htm (accessed: 9.04.2018).

United Nations, "Security Council press statement on Mali," https://minusma.unmissions.org/en/ security-council-press-statement-mali-6 (accessed: 9.04.2018).

United Nations, "Troop and police contributors," https://peacekeeping.un.org/en/troop-and-police-contributors (accessed: 12.04.2019).

United Nations, "UN peacekeeping operations fact sheet," https://minusma.unmissions.org/sites/ default/files/pk_factsheet_01_15_e.pdf (accessed: 9.04.2019)

Vargová K., Role mírových misí OSN při řě̌eni konfliktů: komparace mírových misi v Mali a Demokratické republice Kongo, dissertation at University of West Bohemia, Plzeň 2016.

\section{UNITED NATIONS MULTIDIMENSIONAL INTEGRATED STABILIZATION MISSION IN MALI}

\section{Summary}

The security and political instability of West and Central African countries is influenced by several factors and is a topical issue for the United Nations (UN) and the European Union's (EU) foreign policy. The security of the region decreased to a low level after the declaration of the war on terrorism in 2003. According to the Global Peace Index (GPI), which takes into account the militarization and security of society, countries such as Mali (2.686 - 144), Central African Republic $(3.236$ - 155) or Libya $(3.262$ - 157) compared to other countries of the world have long been in the unflattering index position, which is evaluated by 163 countries. The destabilization of Libya and the consequences of the fall of the dictatorial regime of Muammar Gaddafi led to the subsequent spread of instability in the region in 2011. After the emergence of the radical organization of the Islamic State (IS), as well as other organized armed groups in the Middle East and in some African Union states, fighters are rapidly expanding into Mali, Mauritania and Niger. The UN Multidimensional Integrated Stabilization Mission in Mali (MINUSMA) was launched in July 2013. As asymmetric terrorist attacks on UN peacekeepers have increased, a UN-level debate was held to strengthen the mandate and capabilities of UN MINUSMA. Contributing countries of the African Union were aware of the fact that terrorist attacks could spread to neighboring countries and therefore called on UN Member States to become more actively involved in the mission in Mali. The pre- 
sented article analyzes the political and security situation of Mali and the participation of members of the Army of the Czech Republic at the UN MINUSMA. The author of the article concluded that Mali in the post-conflict reconstruction needs to implement all stages of post-conflict reconstruction and necessarily needs the presence of UN and EU troops.

Participation of members of the Army of the Czech Republic should correspond to the ambitions of the Czech Republic within the EU in achieving the objectives of stabilizing the unstable territories in the neighborhood in order to prevent future potential security risks.

Keywords: post-conflict reconstruction, terrorism, peace mission, jihad.

\section{Zbyšek Korecki}

zbysek.korecki@unob.cz 